\title{
Pengaruh Komitmen Organisasi dan Transparansi Terhadap Kualitas Penyusunan Anggaran Pendapatan dan Belanja Daerah
}

\author{
Ainul Yusna Harahap dan Syardiansah \\ Fakultas Ekonomi, Universitas Samudra, Indonesia \\ *Corresponding author: ainulyusnaharahap@unsam.ac.id
}

\begin{abstract}
ABSTRAK
Penelitian ini bertujuan untuk mengetahui pengaruh komitmen organisasi dan tranparansi terhadap kualitas penyusunan anggaran pendapatan dan belanja daerah. Sampel dalam penelitian ini berjumlah 45 responden. Metode analisis data yang digunakan adalah analisis regresi linier berganda, uji hipotesis menggunakan Uji t, Uji F dan Uji Determinasi. Hasil penelitian secara parsial menunjukkan bahwa komitmen organisasi berpengaruh signifikan terhadap kualitas penyusunan APBD sedangkan transparansi tidak berpengaruh signifikan terhadap kualitas penyusunan APBD.komitmen organisadi dan transparansi secara simultan berpengaruh signifikan terhadap kualitas penyusunan APBD. Hasil koefisien determinasi diperoleh sebesar 0.342 atau 34,2\% komitmen organisasi dan transparansi mempengaruhi kualitas penyusunan APBD dan sisanya sebesar 65,8\% dipengaruhi oleh variabel lain.
\end{abstract}

Kata Kunci: Komitmen Organisasi, Transparansi, Kualitas Penyusunan APBD

\section{ABSTRACT}

The objective of the research was to examine the Effect of organizational commitment and transparency on the quality of the preparation of regional revenue and expenditure budgets. The sample in this study amounted to 45 respondents. The data analysis method used is multiple linear regression analysis, hypothesis testing using $t$ test, $F$ test and determination test. The results of the study partially show that organizational commitment has a significant effect on the quality of APBD preparation while transparency has no significant effect on the quality of APBD preparation. Organizational commitment and transparency simultaneously have a significant effect on the quality of $A P B D$ preparation. The coefficient of determination obtained is 0.342 or $34.2 \%$ of organizational commitment and transparency affects the quality of $A P B D$ preparation and the remaining $65.8 \%$ is influenced by other variables.

Keywords: Organizational Commitment, Transparency, Quality of APBD Preparation

\section{PENDAHULUAN}

Pendanaan pembangunan melalui transfer ke daerah merupakan bagian yang tidak terpisahkan dari pendanaan pembangunan secara nasional. Dana transfer ke daerah terdiri dari dana perimbangan dan dana otonomi khusus serta dana penyesuaian. Alokasi dana transfer ke daerah dari waktu ke waktu mengalami peningkatan seiring pelaksanaan kebijakan desentralisasi dan otonomi daerah. Pengelolaan pendanaan transfer ke daerah senantiasa didorong untuk memenuhi pelaksanaan tata kelola keuangan yang baik, memiliki kinerja terukur dan memiliki akuntabilitas terhadap masyarakat. Hasil akhir yang diharapkan adalah adanya peningkatan pelayanan publik.

Terkait dengan kualitas belanja Anggaran Pendapatan dan Belanja Daerah (APBD) ini masih ditemui beberapa permasalahan yang sering muncul di antaranya masih rendahnya 
kualitas perencanaan di daerah. Di samping itu, belum terintegrasinya perencanaan dan penganggaran di daerah juga masih merupakan permasalahan yang umum di setiap daerah. Permasalahan tersebut diikuti oleh permasalahan lain yaitu porsi terbesar APBD ada pada belanja tidak langsung bukan pada belanja langsung.

Pemerintah kota Medan merupakan salah satu kota di Provinsi Sumatera Utara yang telah menerapkan kebijakan ekonomi yang berfokus kepada pertumbuhan ekonomi yang lebih dinamis dan progresif. Sebagai sektor publik, pemerintah kota Medan harus menyediakan layanan jasa untuk meningkatkan kesejahteraan dan kemakmuran warga Kota Medan, termasuk mengatur pengelolaan keuangan daerah dan menggunakan hasil dari pengelolaan tersebut dalam memaksimalkan potensi yang ada untuk meningkatkan pembangunan. Pemerintah kota Medan termasuk daerah otonom yang menyelenggarakan pemerintahan secara mandiri dan terdesentralisasi. Oleh karena itu, adanya desentralisasi pada pemerintah daerah dan tuntutan masyarakat akan transparansi dan akuntabilitas, maka pemerintah kota Medan harus menyelenggarakan sistem pengelolaan keuangan yang dapat meningkatkan efektivitas dan efisiensi kinerja serta dilakukan secara tertib, taat pada peraturan dan bertanggung jawab.

Pengertian kualitas penyusunan APBD jika mengacu pada model terbaik maka tidak ada satu model yang dapat dikatakan paling berkualitas. Jika mengacu pada nilai-nilai yang akan dicapai, juga tidak ada nilai-nilai tunggal yang paling penting. Kualitas Penyusunan APBD berkaitan dengan pemenuhan nilai-nilai ekonomi, efisiensi, efektifitas, equity atau keadilan, akuntabilitas, dan responsivitas. Ekonomi berarti anggaran tersebut selalu meningkat jumlahnya; Efisien berarti alokasi anggaran sesuai dengan hasil yang didapatkan; Efektif berarti alokasi anggaran sesuai dengan tujuan yang direncanakan; Equity atau Adil berarti alokasi dan hasilnya sesuai dengan nilai keadilan.

Komitmen organisasi dibangun atas dasar kepercayaan pekerja atas nilai-nilai organisasi, kerelaan pekerja membantu mewujudkan tujuan organisasi dan loyalitas untuk tetap menjadi anggota organisasi. oleh karena itu, komitmen organisasi akan menimbulkan rasa ikut memiliki bagi pekerja terhadap organisasi. Komitmen organisasi pula memiliki pengaruh yang signifikan terhadap kinerja karyawan hal ini sesuai dengan penelitian yang dilakukan oleh Latief, dkk (2019) dan Syardiansah, dkk (2020). Jika pekerja merasa jiwanya terikat nilai-nilai organisasional yang ada maka dia akan merasa senang dalam bekerja, sehingga mempunyai tanggung jawab dan kesadaran dalam menjalankan organisasi dan termotivasi dalam menyusun APBD yang berkualitas yaitu mampu membiayai program maupun kegiatan yang bermanfaat untuk kemajuan daerah dan kesejahteraan masyarakat sehingga anggaran yang jumlahnya terbatas dapat dikelola secara efektif dan efisien untuk memenuhi kebutuhan masyarakat yang tak terbatas. Oleh karena itu program harus disusun berdasarkan prioritas sesuai kebutuhan masyarakat.

Pada saat ini kualitas Penyusunan APBD di Kota Medan memang belum dilaksanakan secara optimal. Hal ini dapat dilihat dari rendahnya serapan anggaran yang karena masih adanya pekerjaan fisik yang belum terselesaikan dengan pagu anggaran yang cukup besar, seperti Dinas Pekerjaan Umum (PU), Dinas Kebersihan dan Pertamanan (DKP), Dinas Perumahan Kawasan Permukiman dan Penataan Ruang Kota Medan. Belum terlaksananya penyusunan APBD di kota Medan juga dikarenakan keterbatasan daerah dalam hal sumber daya manusia yang tidak mampu untuk menyusun anggaran berbasis kinerja seperti yang diharapkan serta kurangnya Komitmen dari Seluruh Komponen Organisasi.Pada tahun 2020 pemerintah kota Medan mempunyaiSiLPA sebesar Rp622,43 miliar lebih,yang mana angka 
tersebut naik dari tahun sebelumnya yakni sebesar Rp506, 651 miliar lebih. Ini membuktikan bagaimana kualitas APBD kota Medan yang masih kurang baik dikarenakan untuk anggaran masih terlalu tinggi dibandingkan realisasinya.Selain itu terdapat banyak keluhan masyarakat yang bersangkutan dengan pengalokasian anggaran yang tidak direalisasikan sesuai dengan kebutuhan dan skala prioritas serta kurang menggambarkan aspek ekonomis, efisiensi dan efektivitas. Oleh karena itu, diperlukannya suatu mekanisme penyusunan anggaran yang dapat membantu pemerintah daerah dalam penyusunan APBD agar terciptanya kualitas anggaran yang sesuai dengan tujuan dari pemerintah kota Medan itu sendiri yang sesuai dengan peraturan perundang-undangan yang berlaku.

\section{KAJIAN PUSTAKA}

\section{Kualitas Penyusunan APBD}

Penyusunan APBD merujuk pada Peraturan Menteri Dalam Negeri (Permendagri) Nomor 33 Tahun 2019 tentang Pedoman Penyusunan Anggaran Pendapatan dan Belanja Daerah (APBD). Dalam satu tahun anggaran, dari Januari sampai dengan Desember kegiatan penyusunan APBD harus berlangsung sesuai skedul yang ada. APBD dimulai dengan pelaksanaan Musrenbang, selanjutnya dirumuskan dalam Kebijakan Umum Anggaran (KUA) - Prioritas dan Plafon Anggaran Sementara (PPAS) dan diakhiri dengan pengesahan RAPBD menjadi APBD melalui sidang pleno DPRD yang bersangkutan.

Kualitas Penyusunan APBD dapat dilihat dari hal-hal sebagai berikut : a) Ekonomi, nilai ekonomi dalam belanja daerah dan penyusunan APBD berkaitan dengan jumlah pengeluaran yang selalu meningkat sehingga dianggap APBD tersebut semakin tinggi cakupan belanjanya. b) Efisiensi, nilai efisiensi dalam belanja daerah dan penyusunan APBD berkaitan dengan apa yang dapat dihasilkan dari belanja tersebut dan berapa alokasi biaya untuk itu, terrmasuk alokasi waktu untuk penyusunan APBD. c) Efektivitas, nilai efektivitas dalam belanja daerah dan penyusunan APBD berkaitan dengan apa yang dapat dihasilkan dari belanja tersebut dan apakah yang dihasilkan tersebut memuaskan bagi stakeholders yang ada. d) Equity/Keadilan, nilai keadilan atau equity dalam belanja daerah dan penyusunan APBD berkaitan dengan alokasi anggaran yang memihak pada masyarakat yang lemah atau miskin dan melalui prosedur yang dianggap adil. e) Akuntabilitas, nilai akuntabilitas dalam belanja daerah dan penyusunan APBD berkaitan dengan kelengkapan dan kebenaran dokumen yang relevan dalam belanja dan proses penyusunan APBD, termasuk kemungkinan penelusuran semua proses belanja dan penyusunan APBD. f)Responsivitas, nilai Responsivitas dalan belanja daerah dan penyusunan APBD berkaitan dengan keterbukaan dalam belanja daerah dan penyusunan APBD sehingga memungkinkan semua unsur masyarakat berpartisipasi atau memberikan masukanyang relevan.

\section{Komitmen Organisasi}

Menurut Luthans (2006:226) Komitmen organisasi adalah suatu sikap yang ditunjukkan oleh individu dengan adanya identifikasi, keterlibatan serta loyalitas terhadap organisasi serta adanya keinginan untuk tetap berada dalam organisasi dan tidak bersedia untuk meninggalkan organisasinya dengan alasan apapun.Komitmen organisasi akan mempertahankan kepatuhan dalam penyusunan APBD sesuai dengan peraturan yang berlaku. Komitmen organisasi mengandung pengertian sebagai suatu hal yang lebih dari sekedar kesetiaan yang pasif terhadap organisasi, dengan kata lain komitmen organisasi menyiratkan hubungan karyawan dengan organisasi secara aktif karena karyawan yang menunjukkan komitmen tinggi memiliki 
keinginan untuk memberikan tenaga dan tanggung jawab yang lebih dalam kesejahteraan dan keberhasilan organisasi tempatnya bekerja

Komitmen dalam organisasi menggambarkan relatif kuatnya identifikasi individu dan keterlibatan didalam organisasi. Komitmen organisasi terdiri dari tiga komponen utama yaitu : a) Kepercayaan seseorang yang kuat dan menerima tujuan organisasi, b) Kesediaan seseorang mengupayakan sekuat tenaga untuk menjadi bagian dari organisasi dan c) Keinginan seseorang untuk memelihara anggotanya.

\section{Transparansi}

Menurut Standar Akuntansi Pemerintah dalam Peraturan Pemerintah Nomor 24 Tahun 2005, transparansi adalah memberikan informasi keuangan yang terbuka dan jujur kepada masyarakat berdasarkan pertimbangan bahwa masyarakat memiliki hak untuk mengetahui secara terbuka dan menyeluruh atas pertanggungjawaban pemerintah dalam pengelolaan sumber daya yang dipercayanya dan ketaatannya pada peraturan perundang-undangan.

Teori pemerintah menjelaskan transparansi adalah prinsip yang menjamin akses atau kebebasan bagi setiap orang untuk memperoleh informasi tentang penyelenggaraan pemerintahan, yakni informasi mengenai kebijakan, proses pembuatan, pelaksanaan, dan hasil yang dicapai. Transparansi merupakan salah satu karakteristik dari Good Governance. Transparansi dibangun atas dasar kebebasan memperoleh informasi yang berlaku dengan kepentingan publik secara langsung dapat diperoleh mereka yang membutuhkan.

Sigiro (2016) menyatakan transparansi berpengaruh terhadap responsivitas anggaran. Hal ini mengindikasi bahwa transparansi yang dilaksanakan dengan baik dapat menunjang kualitas penyusunan APBD pada pemerintahan daerah. Membangun rasa kepercayaan antara pemerintah dengan publik dalam setiap kegiatan yang dilakukan permerintah, terutama dalam penyusunan APBD merupakan bentuk transparnsi bagi Publik yang dibutuhkan.

\section{METODE PENELITIAN}

Penelitian ini dilakukan pada Pemerintah Kota Medan.Populasi dalam penelitian ini adalah seluruh entitas akuntansi di lingkungan Pemerintah Kota Medan yang berjumlah 34 Organisasi Perangkat Daerah (OPD) yang terdiri dari Sekretariat DPRD, Sekretariat Daerah 2 bagian, 24 (dua puluh empat) dinas, 8 (delapan) badan, 1 Satuan Polisi Pamong Praja, 1 Inspektorat Daerah dan 21 (dua puluh satu) Kecamatan. Dalam penelitian ini sebanyak 45 (empat puluh lima) orang responden.

Teknik pengambilan sampel adalah teknik sampling jenuh (sensus) seluruh anggota populasi digunakan sebagai sampel. Kuesioner dibagikan kepada pejabat yang memiliki wewenang melaksanakan penyusunan anggaran pada OPD, Pejabat Penatausahaan Keuangan OPD (PPK-OPD), Pejabat Pelaksana Teknis Kegiatan (PPTK), Bendahara Pengeluaran, dan Pembantu Bendahara Pengeluaran.

Metode pengumpulan data yang digunakan dalam penelitian ini adalah melalui penyebaran kuesioner secara digital pada 45 orang responden selaku entitas akuntansi di lingkungan Pemerintah Kota Medan, dan kuisioner ini diberikan bobot penilaian setiap pertanyaan berdasarkan Skala Likert.

Metode analisis data dalam penelitian ini yaitu menggunakan metode kuantitatif dengan analisis regresi linier berganda. Model hubungan variabel dalam penelitian ini adalah : $\mathrm{Y}=\mathrm{a}+$ $\beta_{1} \mathrm{X}_{1}+\beta_{2} \mathrm{X}_{2}+\mathrm{e}$

Dimana: 


$$
\begin{aligned}
& \mathrm{Y}=\text { Kualitas Penyusunan APBD } \\
& \mathrm{X}_{1}=\text { Komitmen Organisasi } \\
& \mathrm{X}_{2}=\text { Transparansi } \\
& \mathrm{A}=\text { Bilangan Konstanta (harga } \mathrm{Y}, \text { bila } \mathrm{X}=0 \text { ) } \\
& \mathrm{E} \quad=\text { Error yang ditolerir }(5 \%)
\end{aligned}
$$

Sedangkan untuk pengujian hipotesis dilakukan dengan: Uji secara parsial (Uji t), yaitu untuk mengetahui pengaruh antara variabel independen dengan variabel dependen secara parsial. Kriteria pengambilan keputusan sebagai berikut: $\mathrm{H}_{\mathrm{o}}$ diterima jika $\mathrm{t}_{\text {signifikan }}>5 \%$ dan $\mathrm{H}_{\mathrm{a}}$ diterima jika $t_{\text {signifikan }}<5 \%$.

Pengujian hipotesis secara Simultan (Uji F)dilakukan untuk menguji signifikansi hubungan antara variabel Xterhadap Y secara simultan.Kriteria pengambilan keputusan sebagai berikut: $\mathrm{H}_{\mathrm{o}}$ diterima jika $\mathrm{F}_{\text {signifikan }}>5 \%$ dan $\mathrm{H}_{\mathrm{a}}$ diterima jika $\mathrm{F}_{\text {signifikan }}<5 \%$.

Dan pengujian Koefesien determinasi dimaksudkan untuk mengetahui tingkat ketepatan paling baik dalam analisis regresi dimana hal yang ditunjuk oleh besarnya koefisien determinasi (Adjusted $\mathrm{R}^{2}$ ) antara 0 (nol) dan 1 (satu). Koefisien determinasi (Adjusted $\mathrm{R}^{2}$ ) nol variabel independen sama sekali tidak berpengaruh terhadap variabel dependen.

\section{HASIL DAN PEMBAHASAN}

Untuk mengetahui besarnya pengaruh komitmen organisasi dan transparansi terhadap kualitas

\begin{tabular}{|c|c|c|c|c|c|c|}
\hline \multicolumn{7}{|c|}{ Coefficients $^{\mathrm{a}}$} \\
\hline \multicolumn{2}{|c|}{ Model } & \multicolumn{2}{|c|}{ Unstandardized Coefficients } & \multirow{2}{*}{$\begin{array}{l}\text { Standardized } \\
\text { Coefficients } \\
\text { Beta }\end{array}$} & \multirow[t]{2}{*}{$\mathrm{t}$} & \multirow[t]{2}{*}{ Sig. } \\
\hline & & $\mathrm{B}$ & Std. Error & & & \\
\hline \multirow[t]{3}{*}{1} & (Constant) & 13,666 & 6,349 & & 2,152 & ,037 \\
\hline & $\mathrm{KO}$ & ,995 & ,208 & 628 & 4,787 &, 000 \\
\hline & $\operatorname{Tr}$ &, 011 &, 109 &, 013 &, 101 & ,920 \\
\hline
\end{tabular}
penyusunan APBD. Analisis ini menggunakan proses input berdasarkan data yang diperoleh dari hasil kuesioner yang disebarkan kepada responden. Hasil pengolahan data dengan bantuan SPSS diperoleh sebagai berikut:

Tabel 1 Hasil Uji Regresi Linear Berganda

Sumber: Data Primer diolah (2021)

Berdasarkan tabel koefisien regresi diatas, pada kolom Coefficients diperoleh model persamaan regresi linear berganda sebagai berikut $\mathrm{Y}=13,666+0,995 \mathrm{KO}+0,011 \mathrm{Tr}+\mathrm{e}$. Dari persamaan regresi linier tersebut dapat dijelaskan bahwanilai sebesar 13,666merupakan nilai konstanta kualitas penyusunan APBD. Artinya nilai kualitas penyusunan APBD akan konstan sebesar 13,666satuan jika komitmen organisasi dan transparansi sama dengan nol atau konstan. Koefisien regresi komitmen organisasi (KO) sebesar 0,995; artinya jika variabel independen lain nilainya tetap dan $\mathrm{KO}$ mengalami kenaikan $1 \%$, maka kualitas penyusunan APBD mengalami kenaikan sebesar 0,995 atau kualitas penyusunan APBD akan semakin baik. Koefisien bernilai positif artinya terjadi hubungan positif atau searah antara komitmen organisasi dengan kualitas penyusunan APBD, semakin baik komitmen organisasi maka kualitas penyusunan APBD semakin baik. Dan sebaliknya jika komitmen organisasi yang tidak baik, maka kualitas penyusunan APBD akan semakin tidak baik juga.Koefisien regresi transparansi ( $\mathrm{Tr})$ sebesar 0,011; artinya jika variabel independen lain nilainya tetap dan $\mathrm{Tr}$ mengalami kenaikan 1\%, maka kualitas penyusunan APBD mengalami kenaikan sebesar 0,011 atau kualitas penyusunan APBD akan semakin baik. Koefisien bernilai positif artinya terjadi hubungan positif atau searah antara transparansi dengan kualitas penyusunan APBD, semakin 
baik transparansi yang dilakukan maka kualitas penyusunan APBD semakin baik. Hal ini didasarkan pada pemikiran dengan adanya transparansi kepada masyarakat, masyarakat tidak hanya untuk mengetahui anggaran tersebut tetapi juga mengetahui pelaksanaan kegiatan yang dianggarkan sehingga pemerintah daerah berusaha dengan baik dalam melaksanakan seluruh perencanaan yang ada karena akan dinilai dan diawasi oleh masyarakat.

Hasil nilai signifikan dari variabel komitmen organisasi $\left(\mathrm{X}_{1}\right)$ mempunyai signifikansi $0,000<0,05$ dan nilai t hitung $4.787>\mathrm{t}$ tabel 1.683. Berdasarkan nilai tersebut disimpulkan bahwa Ha diterima atau dijelaskan bahwa variabel komitmen organisasi secara parsial berpengaruh terhadap kualitas penyusunan APBD. Hasil ini menunjukkan bahwa jika pekerja merasa jiwanya terikat nilai-nilai organisasional yang ada maka dia akan merasa senang dalam bekerja, sehingga mempunyai tanggung jawab dan kesadaran dalam menjalankan organisasi dan termotivasi dalam menyusun APBD yang berkualitas dan tepat sasaran yang nantinya mampu membiayai program maupun kegiatan yang bermanfaat untuk kemajuan daerah dan kesejahteraan masyarakat sehingga anggaran yang jumlahnya terbatas dapat dikelola secara efektif dan efisien untuk memenuhi kebutuhan masyarakat yang tak terbatas. Variabel transparansi $\left(\mathrm{X}_{2}\right)$ mempunyai signifikansi 0,920 > 0,05 dan nilai t hitung 0,101 > t tabel 1.683. berdasarkan nilai tersebut disimpulkan bahwa Ha ditolak atau dijelaskan bahwa variabel transparansi secara parsial tidak berpengaruh terhadap kualitas penyusunan APBD.Hal ini mungkin disebabkan karena para pimpinan OPD merasa kurang pentingnya transparansi kepada masyarakat, sehingga dalam penyusunan APBD tidak dilakukan secara optimal karena merasa tidak diawasi dan dinilai oleh masyarakat.

Tabel 2Hasil Uji Simultan (Uji F)

\begin{tabular}{|c|c|c|c|c|c|c|}
\hline \multicolumn{7}{|c|}{ ANOVA $^{b}$} \\
\hline & & Sum of Squares & Df & Mean Square & $\mathrm{F}$ & Sig. \\
\hline \multirow[t]{3}{*}{1} & Regression & 257,466 & 2 & 85,822 & 8,620 &, $000^{\mathrm{a}}$ \\
\hline & Residual & 408,179 & 42 & 9,956 & & \\
\hline & Total & 665,644 & 44 & & & \\
\hline
\end{tabular}

Sumber: Data Primer diolah (2021)

Dari hasil pengujian terhadap uji Anova atau $F_{\text {test }}$ seperti yang ditampilkan diatas diperoleh nilai $F_{\text {hitung }}$ sebesar 8,620 pada taraf $\alpha=0,05$.dan $F_{\text {tabel }} 2,833$. Dari hasil diatas $F_{\text {hitung }} 8,620>$ $\mathrm{F}_{\text {tabel }} 2,833$ dan $\mathrm{p}$ value pada signifikan dengan level of significant $(\alpha) 0,000<0,05$ dapat disimpulkan bahwa variabel independen yaitu komitmen organisasi dan transparansi berpengaruh terhadap kualiltas penyusunan APBD maka dapat disimpulkan bahwa Ha diterima.

Tabel 3 Koefisien Determinasi

\begin{tabular}{|c|c|c|c|c|}
\hline \multicolumn{5}{|c|}{ Model Summary ${ }^{b}$} \\
\hline Model & $\mathrm{R}$ & R Square & Adjusted R Square & $\begin{array}{l}\text { Std. Error of the } \\
\text { Estimate }\end{array}$ \\
\hline 1 &, $622^{a}$ & ,387 & ,342 & 3,15525 \\
\hline
\end{tabular}

Sumber: Data Primer diolah (2021)

Dari hasil pengolahan SPSS dalam tabel 3dilihat bahwa nilai Adjustud R Square sebesar 0,342. Hal ini berarti variabelkomitmen organisasi dan transparansi mempengaruhi kualiltas penyusunan APBD sebesar 0,342atau 34,2\%, sedangkan sisanya sebesar 65,8\% dipengaruhi oleh variabel lain yang tidak diteliti dalam penelitian ini. 


\section{KESIMPULAN}

Berdasarkan hasil pembahasan diatas dapat disimpulkan bahwa dari hasil uji secara parsial menunjukkan bahwa variabel komitmen organisasi memiliki pengaruh signifikan terhadap kualiltas penyusunan APBD. Sedangkan variabel transparansi berpengaruh tidak signifikan terhadap kualitas penyusunan APBD kota Medan. Dari hasil uji secara simultan menunjukkan bahwa variabel komitmen organisasi dan transparansi berpengaruh signifikan terhadap kualitas penyusunan APBD. Dan dari hasil analisis koefesien determinasi diketahui bahwa komitmen organisasi dan transparansi mempengaruhi kualiltas penyusunan APBD sebesar 0,342atau $34,2 \%$, sedangkan sisanya sebesar $65,8 \%$ dipengaruhi oleh variabel lain yang tidak diteliti dalam penelitian ini.

\section{DAFTAR PUSTAKA}

Abdullah, Thamrin., and Francis Tantri. 2012. Manajemen Pemasaran. PT Raja.Grafindo Persada : Jakarta.

Achyani, F., \& Cahya, B. T. 2011. Analisis Aspek Rasional dalam Penganggaran Publik Terhadap Efektivitas Pengimplementasian Anggaran Berbasis Kinerja Pada Pemerintah Kota Surakarta. Maksimum, Vol 1, No 1.

BPKP. 2005. Pedoman Peyusunan Anggaran Berbasis kinerja (Revisi). Jakarta

Fandy, Tjiptono dan Greforius, Chandra. 2016. Pemasaran Jasa (Prinsip, Penerapan, dan Penelitian), Yogyakarta: Andi.

Ghozali, I. 2008. Model persamaan struktural: Konsep dan aplikasi denganprogram AMOS 16.0. Badan Penerbit Universitas Diponegoro

Ghozali, I. 2013. Aplikasi Analisis Multivariat dengan Program IBM SPSS 21. Edisi 7, Penerbit Universitas Diponegoro, Semarang. Quarterly Journal of Economics, 128, 1547-1584.

Hair, J. F., Ringle, C. M., \& Sarstedt, M. 2011. PLS-SEM: Indeed a silver bullet.Journal of Marketing theory and Practice, 19(2), 139-152.

Heidjrachman dan Husnan 2012. Manajemen Personalia. Yogyakarta: Andi.

Keputusan Menteri Dalam Negeri nomor 29 tahun 2002 yang sekarang berubah menjadi Permendagi Nomor 52 Tahun 2015

Latan, H., \& Ghozali, I. 2015. Partial least square konsep, metode dan aplikasi menggunakan program WarpPLS 2.0. Semarang: Badan Penerbit Universitas Diponegoro.

Latief, A. Syardiansah. Sfwan, M. 2019. Pengaruh Komitmen Organisasi dan Kepuasan Kerja Terhadap Kinerja Karyawan Badan Penyelenggara Janiman Sosial Kesehatan. Jurnal Administrasi Publik : Public Administration Journal. 9(1):41-51

Mardiasmo. 2009. Akuntansi Sektor Publik. Andi, Yogyakarta.

Nafarin, M. 2013. Penganggaran Perusahaan. Edisi ketiga, Cetakan kedua, Buku 1. Jakarta : Salemba Empat

Nawawi, Hadari, 2013. Manajemen Sumber Daya Manusia Untuk Bisnis Yang Kompetitif, Yogyakarta: Gajah Mada University Press

Peraturan Menteri Dalam Negeri nomor 13 tahun 2006 tentang pedoman pengelolaan keuangan daerah

Peraturan Menteri Pendayagunaan Aparatur Pemerintah Nomor 14 Tahun 2014 tentang Pedoman Evaluasi Reformasi Birokrasi Instansi Pemerintah

PP No. 21/2004 pasal 7 ayat 1 dan 2, penganggaran berbasis kinerja PP Nomor 58 tahun 2005 proses perencanaan dan penyusunan APBD Sinulingga S. 2014. Rekayasa Produktivitas. Medan: USU Press.

Sugiyono. 2012. Memahami Penelitian Kualitatif. Bandung : ALFABETA 
.2014. Metode Penelitian Pendidikan Pendekatan Kuantitatif,. Kualitatif, dan R\&D. Bandung: Alfabeta.

Syardiansah. Mora, Z. Safriani. 2020. Pengaruh Kepuasan Kerja, Budaya Organisasi dan Komitmen Organisasi Terhadap Kinerja Karyawan. Jurnal Pendidikan Ilmu-ilmu Sosial. 12(2):438-444

Undang - Undang Nomor 17 Tahun 2003 tentang Keuangan Negara pasal 19 menetapkan bahwa APBD

Undang-Undang No. 17 tahun 2003 tentang Keuangan Negara, Undang-Undang No. 32 dan 33 Tahun 2004 tentang Otonomi Daerah Undang-Undang No. 17 tahun 2003 tentang Keuangan Negara

Undang-Undang Nomor 33 tahun 2004 tentang Perimbangan Keuangan Antara Pemerintah Pusat dan Pemerintah Daerah.

Verasvera, Febrina Astria. 2016. "Pengaruh Anggaran Berbasis Kinerja Terhadap Kinerja Aparatur Pemerintah Daerah". Jurnal Manajemen, Vol.15 No.2, Mei, hal. 137-162. 